\title{
The Effectiveness of Solar Panels from the Installation Location
}

\author{
Yessi Marniati ${ }^{1, *}$ Herman Yani $^{1}$ Nofiansah Nofiansah ${ }^{1}$ Siswandi Siswandi ${ }^{1}$ \\ ${ }^{1}$ Department of Electrical Engineering, Polytechnic State of Sriwijaya, Palembang, Indonesia \\ *Corresponding author. Email: yessi_pdg@polsri.ac.id
}

\begin{abstract}
The location of the solar panel installation affects the intensity of the light absorbed. Of the three test locations; on the roof, on the ground, on the water, the most significant increase in light intensity is on the roof. The position of the solar panel is at $30^{\circ}$, the average light intensity is $80300 \mathrm{lux}$, the average current is $2.38 \mathrm{~A}$, the average voltage is $230.2 \mathrm{~V}$, the average power is $40.99 \mathrm{~W}$, when the surface of the solar panel is exposed to the sun, the hot steam from the roof affects the surface of the panel the sun so that the light intensity increases. The installation location is above the ground, the average light intensity value is $76960 \mathrm{lux}$, the average current is $1.37 \mathrm{~A}$, the average voltage is $230.28 \mathrm{~V}$, the average power is $39.15 \mathrm{~W}$. The installation location on the water, the average light intensity value is 42680 lux, the average current is $1.33 \mathrm{~A}$, the average voltage is $230.34 \mathrm{~V}$, the average power is $38.69 \mathrm{~W}$, smaller than the two previous locations. So, the location of the solar panel installation greatly affects the light intensity, current, voltage and power. The greater the light intensity, the higher the current, voltage and power and vice versa.
\end{abstract}

Keywords : Solar Panel, Effectiveness, light intensity, current, voltage

\section{INTRODUCTION}

Solar cells or PV cells rely on the photovoltaic effect to absorb solar energy and cause current to flow between two oppositely charged layers. The main components of PLTS consist of solar panels, inverters, and batteries. Solar Panel (photovoltaic) is the main component in PLTS, serves to convert sunlight energy into DC electrical energy. Inverter is a direct voltage (DC) converter from solar panels into alternating voltage (AC) to supply electricity to users. In its use, many solar panels are installed statically and do not take into account the optimal point of sunlight. This causes the received solar intensity to be less than optimal. To maximize the absorption of sunlight intensity in the formation of a perpendicular angle between the solar panels and the direction of the sun's rays. Therefore, the solar panel needs to be moved according to the angle of the sun's orientation, so that the intensity of sunlight captured by the surface of the solar panel is optimal and the installation location also plays a very important role in its effectiveness. The location of the installation is very influential on the intensity of the current, voltage, power and duration of use of the solar panel. So that when the intensity of sunlight is captured by the solar panel optimally from morning to evening, the voltage and current generated will increase. Optimizing the resulting voltage and current, will automatically increase the output power of the solar panel, and the battery will be charged quickly.

\subsection{Problem Formulation}

Based on the background that has been stated previously, the problems in the research can be formulated as follows

1. How is the value of current, voltage, power and light intensity absorbed by solar panels in a state of sunlight intensity with $30^{\circ}$ angles solar panels.

2. What is the value of current, voltage and power absorbed by the solar panels with three different solar panel installation locations (on the roof, in the field and on the water).

3. How is the effectiveness of solar panels on the effect of changes in sunlight intensity with different solar panel position angles from $30^{\circ}$. 


\subsection{Troubleshooting}

To focus this research, as for the limitations of the problem in this study, the authors focus on the influence of the angle of the solar panel position, which is $30^{\circ}$, as an optimizer of the intensity of sunlight captured by the solar panel with the output values of current, voltage, power and intensity the intensity of the light produced corresponds to three diffrerent installation locations (on the roof, on the ground and over the water).

\subsection{Research Objectives}

This research was conducted with the following objectives

1. To find out the value of current, voltage, power and light intensity absorbed by the solar panel with the angle of the solar panel position of $30^{0}$

2. To find out how much current, voltage and power the solar panels absorb with three different solar panel installation locations (on the roof, on the ground and above the water).

3. To determine the effectiveness of solar panels on the effect of changes in the intensity of sunlight with the position of the solar panel at an angle of $30^{\circ}$

\subsection{Research Outcomes}

Outcome targets are in accordance with the targeted science and technology outputs:

\subsubsection{Mandatory Outcomes}

1. Produce journals published in international scientific journals

2. Participate in international seminars

\subsubsection{Additional Output}

1. This research document produces a renewable energy practicum module

\subsection{Research Contribution}

1. Can provide a reference for further researchers to conduct research on the effectiveness of solar panels from the installation location of changes in angle and light so that they can be examined more deeply

2. Can be used as a reference for students of State Polytechnic of Sriwijaya majoring Electrical Engineering Study Program in making the final report (LA)

\subsection{Literature Review}

\subsubsection{Photovoltaic (PV) Module}

Photovoltaic modules use light energy (photons) from the Sun to generate electricity through the photovoltaic effect. The cells are usually connected electrically and in series, with each other with the desired voltage, and then in parallel to increase the current while the power (in watts) of the module is the value of the current and voltage. One solar cell can produce a potential difference of $0.5 \mathrm{~V}$ DC (in full light). Several cells can be lined up to obtain a voltage of $6,9,12,24$ and so on. Solar cells can also be aligned to obtain a larger output current.

\subsubsection{Solar Cell Operating Factor}

The maximum operation of a solar cell is highly dependent on:

\subsubsection{Ambient Air Temperature}

A solar cell can operate optimally if the cell temperature remains normal (at 25 degrees celsius), an increase in temperature higher than the normal temperature in photovoltaic (PV) will weaken the voltage (Voc).

\subsubsection{Solar Radiation}

Solar radiation from the sun on earth and in various locations is variable, and is very dependent on the state of the solar spectrum to the earth. Solar solar insolation will have a lot of effect on current (I) slightly on voltage. (see diagram image).

\subsubsection{Optimum Orientation of The PV Circuit}

\subsubsection{Towards The Sun}

Optimum orientation of the PV array towards the sun is important so that the $\mathrm{PV}$ array/panel can produce maximum energy, in addition to the orientation direction, the tilt angle of the PV array panel also greatly affects the maximum energy yield (see tilt angle work).

\subsubsection{Sun Orientation Angle}

The angle of the sun's orientation keeps the sun's rays falling on a PV panel surface perpendicularly will get a maximum energy of $\pm 1000 \mathrm{~W} / \mathrm{m} 2$ or $1 \mathrm{Kw} / \mathrm{m} 2$. If it is not possible to maintain the perpendicularity between sunlight and the PV plane, then an extra PV panel area is needed (PV panel area to sun altitude which changes every hour of the day). 


\subsubsection{Solar Panel Area}

The area of the solar panel module used to support how much power can be absorbed by the solar panel can be calculated as follows:

$$
\mathrm{A}=\mathrm{P} . \mathrm{L}
$$

Where:

$\mathrm{A}=$ Solar module surface area $(\mathrm{m} 2)$

$\mathrm{P}=$ Solar module length $(\mathrm{m})$

$\mathrm{L}=$ solar module width $(\mathrm{m})$

\subsubsection{Power On Solar Panel}

Electrical power is an electrical quantity that states the amount of energy used to activate electrical/electronic components or equipment. The intensity of light determines the amount of power from the energy of the light source that reaches the entire surface of the solar cell. If the surface area of the solar cell (A) is of a certain intensity, then the input power of the solar cell is:

$$
P_{\text {in }}=\mathrm{E} . \mathrm{A} \text {. }
$$

Where :

$\mathrm{P}_{\mathrm{in}}=$ Power received due to solar irradiance (Watt)

$\mathrm{E}=$ Light Intensity $(\mathrm{W} / \mathrm{m} 2)$

$\mathrm{A}=$ Surface area of solar cells (m2)

$$
\mathrm{P}=\mathrm{V} \times \mathrm{I} \text {. }
$$

Where

$\mathrm{P}=$ Output power (Watts)

$\mathrm{V}=$ Output voltage (Volts)

$\mathrm{I}=$ Current (Amperes)

$$
\mathrm{P} \text { rata } \operatorname{rata}=\mathrm{P}_{1}+\mathrm{P}_{2}+\ldots+\mathrm{P}_{\mathrm{n}} / \mathrm{n}
$$

$\mathrm{P}_{1}=$ Power at the first test point.

$\mathrm{P}_{2}=$ Power at the second test point.

$\mathrm{Pn}=$ Power at the nth test point.

\subsubsection{Components of Solar Power Generation}

The components needed for solar power installations consist of:

1. Solar panels. Solar panels convert solar energy into electricity.

2. Solar Charge Controller. The solar charge controller functions to regulate traffic from the solar panel to the battery and load.

3. Battery. The battery functions to store the electric current generated by the solar panel before it is used to drive the load
4. Inverter. An inverter is an electrical power converter that converts direct current (DC) into alternating current (AC).

5. Cable. Electrical cables are used to connect two or more devices, enabling the transfer of electrical signals or power from one device to the other.

\section{METHOD}

The implementation of this research uses several methods, while the methods used during this research are as follows:

1. Observation method, this method is carried out through direct research in the field according to the conditions in question and in the laboratory of the Electrical Engineering study program related to the problem to be studied.

2. Literature Method, collects the necessary data by reading books, internet and literature related to the problem to be studied.

3. Consultation method, the method used is to ask colleagues who have expertise in accordance with the title of the proposer.

Research and data collection were carried out in several places at Sekip Madang in Palembang City. This research will be carried out from July to November 2021. This research will be carried out by testing solar panels that have been assembled in series. The solar panels used are made of polycrystalline.

\subsection{Diagram Block}

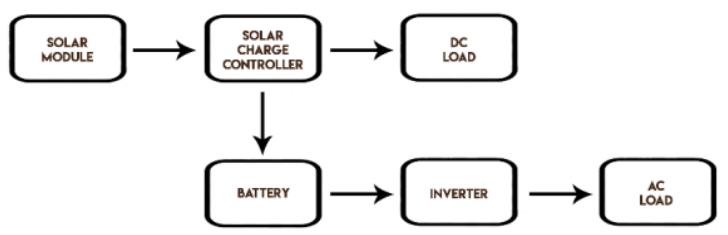

Figure 1 Diagram Block 


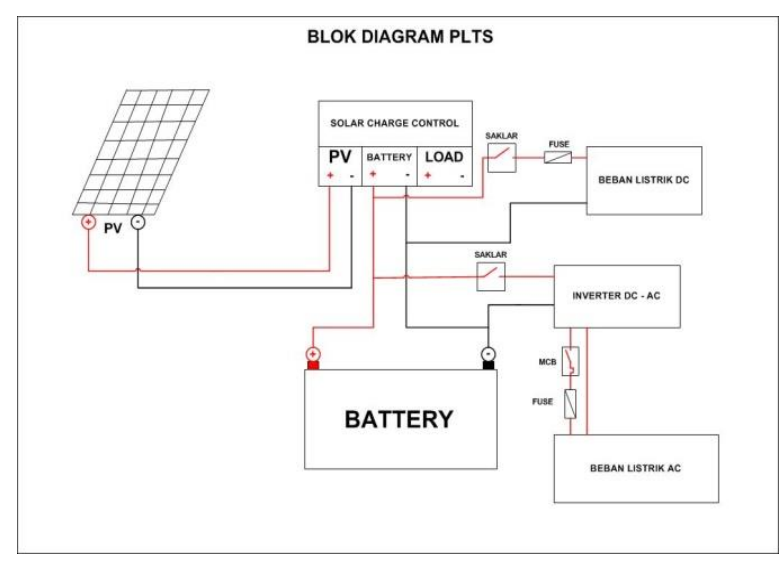

Figure 2 solar panel power plant circuit

\section{RESULT AND DISCUSSION}

The research will be conducted by testing solar panels using angle of $30^{\circ}$, and on different days. Then the solar panels are tested and measured to determine the value of current, voltage, power and intensity. Methods of calculation and measurement with data collection, this test was carried out in the Sekip Madang area of Palembang City.

The steps are as follows:

1. The research will start with collecting data and references, looking for tools and materials needed in the research up to the testing stage on solar panels that have been set with a tilt angle of $30^{\circ}$.

2. Perform testing using the same time load (Lamp) with different hours and days, each test and measurement data is taken respectively. And calculated to get the required power.

3. Conduct a discussion and analysis of the test results and then draw conclusions to arrive at the final stage, namely the completion of the research report.

Table 1. Test Results and Calculation of Solar Panels with Angle $30^{\circ}$

\begin{tabular}{|c|c|c|c|c|c|}
\hline \multicolumn{6}{|c|}{ On The Roof } \\
\hline No. & Time & Current (A) & Voltage (V) & Power $(\mathrm{W})$ & $\begin{array}{l}\text { Light Intensity } \\
\text { (Lux) }\end{array}$ \\
\hline 1 & $08.00 \mathrm{WIB}$ & 2.63 & 231 & 39.27 & 524 \\
\hline 2 & $10.00 \mathrm{WIB}$ & 2.65 & 231,1 & 39,29 & 1053 \\
\hline 3 & $12.00 \mathrm{WIB}$ & 4.17 & 228,6 & 38.86 & 1450 \\
\hline 4 & $14.00 \mathrm{WIB}$ & 1.3 & 230.7 & 46.14 & 589 \\
\hline 5 & 16.00WIB & 1.18 & 230 & 41.4 & 401 \\
\hline & Rata-Rata & 2.39 & 230.3 & 40.99 & 80340 \\
\hline \multicolumn{6}{|c|}{ On The Ground } \\
\hline No. & Time & Current (A) & Voltage (V) & Power $(\mathrm{W})$ & $\begin{array}{l}\text { Light Intensity } \\
\text { (Lux) }\end{array}$ \\
\hline 1 & $08.00 \mathrm{WIB}$ & 0.35 & 232 & 39.44 & 245 \\
\hline 2 & $10.00 \mathrm{WIB}$ & 2.35 & 229.3 & 38.98 & 998 \\
\hline 3 & $12.00 \mathrm{WIB}$ & 3.95 & 229.6 & 39.03 & 1131 \\
\hline 4 & $14.00 \mathrm{WIB}$ & 0.99 & 229.9 & 39.08 & 1028 \\
\hline 5 & 16.00WIB & 0.20 & 230.6 & 39.2 & 446 \\
\hline \multicolumn{2}{|r|}{ Rata-Rata } & 1.57 & 230.3 & 39.15 & 76960 \\
\hline \multicolumn{6}{|c|}{ On The Water } \\
\hline No. & Time & Current (A) & Voltage (V) & Power $(\mathrm{W})$ & $\begin{array}{l}\text { Average Light } \\
\text { Intensity (Lux) }\end{array}$ \\
\hline 1 & $08.00 \mathrm{WIB}$ & 1.01 & 229.9 & 39.08 & 429 \\
\hline 2 & $10.00 \mathrm{WIB}$ & 2.64 & 231.2 & 36.99 & 683 \\
\hline 3 & $12.00 \mathrm{WIB}$ & 2.03 & 232.2 & 39.47 & 613 \\
\hline 4 & $14.00 \mathrm{WIB}$ & 0.93 & 230.2 & 39.13 & 387 \\
\hline 5 & 16.00WIB & 0.04 & 228.2 & 38.79 & 22 \\
\hline \multicolumn{2}{|r|}{ Rata-Rata } & 1.33 & 230.34 & 39.69 & 42680 \\
\hline
\end{tabular}




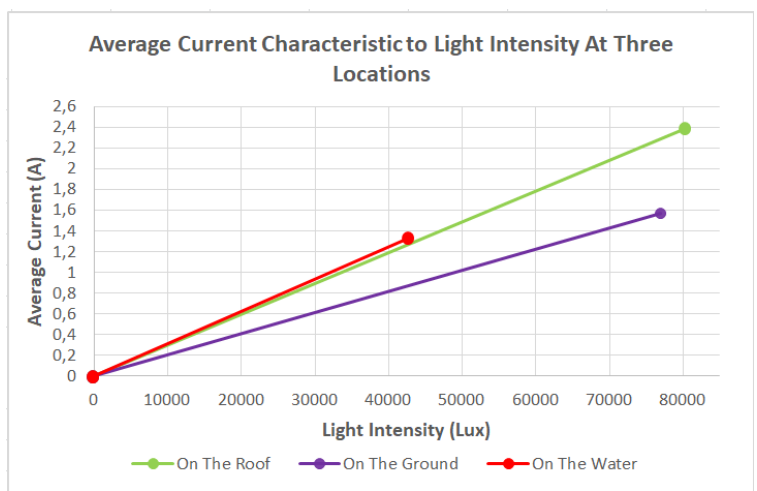

Figure 3 average current characteristic curve to light intensity at three locations

From the value of the average light intensity and average current in Figure 3 above with a solar panel tilt angle of $30^{\circ}$, where the largest average current value is obtained at the installation location on the roof. which is $2.39 \mathrm{~A}$. While on the ground the average current value is $1.57 \mathrm{~A}$ and the smallest average current value is obtained at the installation location on the water, which is $1.33 \mathrm{~A}$. This is due to the influence of hot steam from the roof affects the surface of the solar panel so that its intensity increases, as well as the installation location on the water, water vapor affects the surface of the solar panel which causes the intensity to decrease.

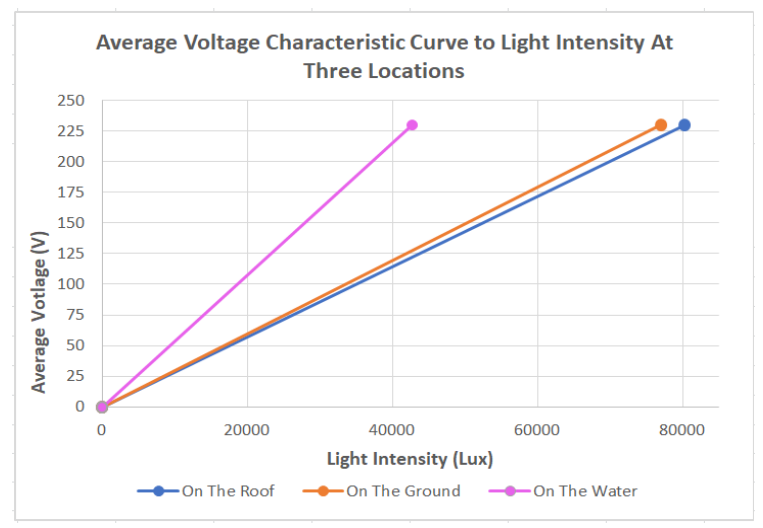

Figure 4 average voltage characteristic curve to light intensity at three locations

From Figure 4 it can be seen that the average stress values obtained from the three installation locations are above the roof, above the ground, and above the water. The average voltage value obtained at the installation location on the roof and above the ground is the same, which is 230.3 Volts. while the average voltage value obtained at the installation location on the water is 230.34 Volts. This is in accordance with the equation where the voltage value is directly proportional to the light intensity.

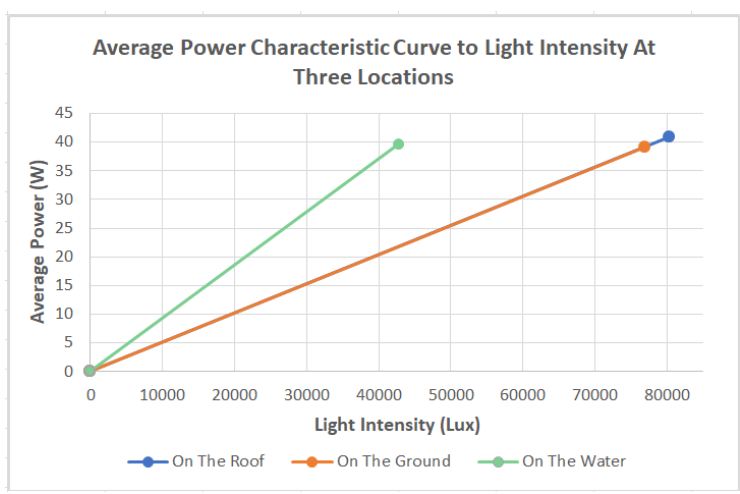

Figure 5 average power characteristic curve to light intensity at three locations

Figure 5 above shows the average light intensity and average power with an angle of $30^{\circ}$, at the installation location on the roof the average power value obtained is $40.99 \mathrm{~W}$, above ground is $39.15 \mathrm{~W}$, and over water is $39.69 \mathrm{~W}$. This average power value is the result of the calculation of the voltage and current obtained from the measurement results, where the greater the light intensity, the current, voltage and power also increase. conversely, if the light intensity decreases, the voltage, current, and power also decrease. More importantly, the installation location greatly influences the test and measurement results.

\section{CONCLUSION}

The location of the solar panel installation affects the intensity of the light absorbed. Of the three test locations; on the roof, on the ground, on the water, the most significant increase in light intensity is on the roof. The position of the solar panel is at $30^{\circ}$, the average light intensity is 80300 lux, the average current is $2.38 \mathrm{~A}$, the average voltage is $230.2 \mathrm{~V}$, the average power is $40.99 \mathrm{~W}$, when the surface of the solar panel is exposed to the sun, the hot steam from the roof affects the surface of the panel the sun so that the light intensity increases. The installation location is above the ground, the average light intensity value is 76960 lux, the average current is $1.37 \mathrm{~A}$, the average voltage is $230.28 \mathrm{~V}$, the average power is $39.15 \mathrm{~W}$. The installation location on the water, the average light intensity value is 42680 lux, the average current is $1.33 \mathrm{~A}$, the average voltage is $230.34 \mathrm{~V}$, the average power is $38.69 \mathrm{~W}$, smaller than the two previous locations. So, the location of the solar panel installation greatly affects the light intensity, current, voltage and power. The greater the light intensity, the higher the current, voltage and power and vice versa. 


\section{REFERENCES}

[1] Berahim H. 1994. "Pengantar Teknik Tenaga Listrik", penerbit Andi Offset. Yogyakarta.

[2] Daryanto. 2014. "Konsep Dasar Teknik Elektronika Kelistrikan.” Edisi pertama Penerbit Alfabet. Bandung

[3] John Bird. 2013. "Electrical Circuit Theory and Technology." Third edition, Newnes, USA

[4] Rif'an. Muhammad. 2012. “Optimasi Pemanfaatan Energi Listrik Tenaga Matahari di Jurusan Teknik Elektro Universitas Brawijaya." Universitas Brawijaya. Malang

[5] ^ "Solar PV capacity factor globally 2020". Statista. Retrieved 14 July 2021.
[6] Orcutt, Mike. "Managing Light To Increase Solar Efficiency". MIT Technology Review. Archived from the original on 20 February 2016. Retrieved 14 March2018.

[7] "Improving the efficiency of solar panels". The Hindu. 24 October 2013. Retrieved 24 October 2013.

[8] Photovoltaics Report, Fraunhofer ISE, 28 July 2014, pages 18,19

[9] Dunlop, James P. (2012). Photovoltaic systems. National Joint Apprenticeship and Training Committee for the Electrical Industry (3rd ed.). Orland Park, IL: American Technical Publishers, Inc. ISBN 978-1-935941-05-7. OCLC 828685287 